\title{
Association of Overweight and Consistent Anovulation among Infertile Women with Regular Menstrual Cycle: A Case-control Study
}

\section{Associação entre sobrepeso e anovulação consistente em mulheres inférteis com ciclo menstrual regular: Um estudo de caso-controle}

\author{
Christiane Ricaldoni Giviziez ${ }^{1}$ Eliane Gouveia de Morais Sanchez ${ }^{1}{ }^{(0)}$ \\ Yanna Andressa Ramos de Lima ${ }^{2(1)}$ Mário Silva Approbato ${ }^{2(1)}$
}

\author{
1 Unidade Acadêmica de Ciências da Saúde, Universidade Federal de \\ Jataí, Jataí, GO, Brazil \\ 2 Departamento de Ginecologia e Obstetrícia, Faculdade de Medicina, \\ Hospital das Clínicas, Laboratório de Reprodução Humana, \\ Universidade Federal de Goiás, Goiânia, GO, Brazil
}

\begin{abstract}
Address for correspondence Christiane Ricaldoni Giviziez, PhD, Universidade Federal de Jataí, Cidade Universitária, BR 364, Km 195 , 3800, 75801-615, Jataí, GO, Brasil (e-mail: christiane_giviziez@ufj.edu.br).
\end{abstract}

Rev Bras Ginecol Obstet 2021;43(11):834-839.

\begin{abstract}
Keywords

- female infertility

- anovulation

- overweight

- assisted reproductive techniques
\end{abstract}

\section{Resumo}

Objective It has been suggested that excess body weight could represent a risk factor for infertility outcomes. The present study aimed to evaluate the association of overweight and anovulation among infertile women with regular menstrual cycles. Methods We conducted a retrospective case-control study with consistently anovulatory patients undergoing assisted reproduction treatment. The patients were stratified into normal weight (body mass index [BMI]: $18.5-24.9 \mathrm{~kg} / \mathrm{m}^{2}$ ) and overweight (BMI: $25.0-$ $29.9 \mathrm{~kg} / \mathrm{m}^{2}$ ). Those with polycystic ovary syndrome or obesity were excluded. The groups were matched for age, duration of infertility, prolactin, follicle stimulating hormone (FSH), thydroid stimulating hormone (TSH), luteinizing hormone (LH), and estradiol levels.

Results Overweight was significantly associated with anovulation, when using the World Health Organization (WHO) criteria for anovulation: progesterone levels $>5.65$ $\mathrm{ng} / \mathrm{ml}$ and ultrasonography evidence of follicle collapse (odds ratio [OR]: $2.69 ; 95 \%$ confidence interval [Cl95\%]: 1.04-6.98).

Conclusion Body mass index above the normal range jeopardizes ovulation among non-obese infertile women with regular menstrual cycles.

Objetivo O excesso de peso corporal tem sido associado como fator de risco para infertilidade. Este estudo teve como objetivo avaliar a associação de sobrepeso e anovulação entre mulheres inférteis com ciclos menstruais regulares.

Métodos Realizamos um estudo retrospectivo de caso-controle com mulheres com anovulação consistente em tratamento por reprodução assistida. As pacientes foram received

December 3, 2019

accepted

September 3, 2021
DOI https://doi.org/ 10.1055/s-0041-1739464. ISSN 0100-7203.
(C) 2021. Federação Brasileira de Ginecologia e Obstetrícia. All rights reserved.

This is an open access article published by Thieme under the terms of the Creative Commons Attribution License, permitting unrestricted use, distribution, and reproduction so long as the original work is properly cited. (https://creativecommons.org/licenses/by/4.0/)

Thieme Revinter Publicações Ltda., Rua do Matoso 170, Rio de Janeiro, RJ, CEP 20270-135, Brazil 
estratificadas entre aquelas com peso normal (índice de massa corporal [IMC]: 18,5$24,9 \mathrm{Kg} / \mathrm{m}^{2}$ ) e as com sobrepeso (IMC: $25,0-29,9 \mathrm{Kg} / \mathrm{m}^{2}$ ). As pacientes com síndrome do ovário policístico ou obesidade foram excluídas. Os grupos foram pareados por idade, duração da infertilidade, níveis de prolactina, hormônio folículo-estimulante (FSH), hormônio tiroestimulante (TSH), hormônio luteinizante (LH) e estradiol.

Palavras-chave

- infertilidade feminina

- anovulação

- sobrepeso

- técnicas de reprodução assistida
Resultados $\mathrm{O}$ excesso de peso associou-se significativamente à anovulaçãoquando usados os critérios de anovulação da Organização Mundial de Saúde (OMS): níveis de progesterona $>5,65 \mathrm{ng} / \mathrm{ml}$ e evidência ultrassonográfica de colapso folicular (razão de chances [RC]: 2,69; IC95\%: 1,04-6,98).

Conclusão O IMC acima da faixa normal compromete a ovulação em mulheres inférteis não obesas com ciclos menstruais regulares.

\section{Introduction}

Body mass index (BMI) is associated with risk for diabetes mellitus, arterial hypertension, obstructive sleep apnea, cancer, dyslipidemia, and cardiovascular disease. ${ }^{1}$ Puberty, ovulation and reproductive function are biological events highly dependent on body energetic reserves. In this regard, variables such as weight, body composition, body fat distribution, and the effects of diet and physical exercise have been investigated in women with alterations in sexual maturation, menstrual cycle, and fertility. ${ }^{2-4}$

Extremes in body size, such as thinness and obesity, are considered risk factors for ovulatory infertility among women. ${ }^{5}$ Excess body weight is also associated with disorders of the menstrual cycle and infertility, especially ovulation disorders. $^{6}$ Infertile women with overweight present higher rates of oligomenorrhea, amenorrhea, hirsutism, and hormonal changes than infertile women with a normal BMI. ${ }^{7}$ Ovulatory disorders represent 25 to $50 \%$ of all causes of infertility in women, and a significant proportion is directly or indirectly related to overweight and obesity. ${ }^{8}$

The negative effects of female obesity on reproduction are associated with increased risk of miscarriage, decrease in pregnancy rate, worse results in assisted reproduction treatments, and lower rates of live births. ${ }^{9-12}$ However, previous studies demonstrate controversial effects of high BMI, especially with regard to the results of assisted reproduction treatment. ${ }^{13}$ These differences can be explained by the clinical, methodological and statistical heterogeneity of the studies, as well as the differences found in the definition of a normal BMI characteristic of overweight and obesity. ${ }^{14}$

Therefore, the present study aimed to evaluate the association of overweight and ovulation profile among infertile women searching for assisted reproduction treatment with regular menstrual cycles and not diagnosed with polycystic ovary syndrome or obesity.

\section{Methods}

A retrospective case-control study was conducted to evaluate the association of overweight and ovulation profile among patients with regular menstrual cycles.The current study was submitted and approved by the ethical review board of the university hospital of Universidade Federal de Goiás (protocol $\mathrm{n}^{\circ} 751,390$ ), where the recruitment of patients was performed.

This retrospective study was performed at the Human Reproduction Laboratory of the University Hospital in Goiás, Midwest Brazil (LabRep). LabRep is a public health service that provides low cost assisted reproduction treatment for infertile patients.

We evaluated 7,200 medical records of female patients searching for assisted reproduction treatment between January 2004 and December 2014. According to the inclusion criteria, patients with regular menstrual cycle (25-35 days), aged between 20 and 40 years, and with BMI between 18.5 and $29.9 \mathrm{~kg} / \mathrm{m}^{2}$ (normal and overweight) were selected. Patients were excluded when presenting previous diagnosis of polycystic ovary syndrome (PCOS), as established by the Rotterdam consensus on diagnostic criteria (20); BMI > 29.9 $\mathrm{kg} / \mathrm{m}^{2}$ (obesity); follicle-stimulating hormone $(\mathrm{FSH})>9.9$ $\mathrm{nUI} / \mathrm{mL}$; thyroid-stimulating hormone (TSH) between $0.4-$ $5.0 \mathrm{mIU} / \mathrm{mL}$; serum prolactin level $>20 \mathrm{ng} / \mathrm{mL}$; self-reported diabetes; history of endometriosis, ovarian tumors, or use of medicines that interfere with ovulation.

The case and control groups were defined by the ovulation outcome, defined as consistent non-ovulatory (anovulation) or consistent ovulatory (ovulation), respectively. The exposure variable was overweight, defined by BMI above the normal range and below the obesity range.

Body mass index was calculated according to the Quetelet formula, defined as the weight in kilograms divided by the square of the height in meters $\left(\mathrm{Kg} / \mathrm{m}^{2}\right)$. Patient's weight and height were evaluated at the time of the first medical attendance by an experienced nurse. Normal weight was considered when the patient's BMI was between 18.50 and $24.99 \mathrm{~kg} / \mathrm{m}^{2}$, and overweight was considered when the patient's BMI was between 25.00 and $29.99 \mathrm{~kg} / \mathrm{m}^{2}$.

Consistent ovulation or anovulation was defined by the agreement of two parameters: ultrasound monitoring of ovarian follicles and serum progesterone levels dosed 1 week after follicular collapse. Ultrasound monitoring of ovulation was performed between the $2^{\text {nd }}$ and $5^{\text {th }}$ day of the menstrual cycle, re-examined between the $9^{\text {th }}$ and $10^{\text {th }}$ day and on alternate days until ovulation or until the $16^{\text {th }}$ day, in cases with no development of dominant follicles or follicular 
collapse. Examinations were performed by an experienced medical doctor.

According to the World Health Organization (WHO), serum progesterone levels higher than $5.65 \mathrm{ng} / \mathrm{mL}$ are suggestive of ovulation. However, progesterone levels higher than $10 \mathrm{ng} / \mathrm{mL}$ are considered a more reliable threshold to predict ovulatory function according to the American Society for Reproductive Medicine (ASRM). ${ }^{15}$

To further evaluate the ovulatory function in this set of patients, we used two thresholds for serum progesterone levels indicative of ovulation. We first considered as consistently ovulatory those patients with serum progesterone levels $>5.65 \mathrm{ng} / \mathrm{mL}$ (according to WHO) and with follicle collapse observed at ultrasonography (USG). In a second moment, we considered the progesterone levels $\geq 10.00 \mathrm{ng} / \mathrm{mL}$ (according to the ASRM) as indicative of ovulation, in association with USG evidence. Anovulation was considered when progesterone levels were $\leq 5.65 \mathrm{ng} / \mathrm{mL}$ or $<10.0 \mathrm{ng} / \mathrm{mL}$ with an associated absence of follicle collapse observed at USG.

Additionally, to compare serum progesterone levels among women with normal weight and progressive BMI ranges, the patients were stratified within four categories according to BMI: range I (normal weight with BMI $18.5-22.9 \mathrm{~kg} / \mathrm{m}^{2}$ ); range II (normal weight with BMI $23.0-24.9 \mathrm{~kg} / \mathrm{m}^{2}$ ); range III (overweight with BMI $25.0-27.5 \mathrm{~kg} / \mathrm{m}^{2}$ ); and range IV (overweight with BMI $27.5-29.9 \mathrm{~kg} / \mathrm{m}^{2}$ ). Medians of serum progesterone levels were obtained for each category.

The matching criteria used for case an control groups included: age (years), infertility duration (months), and serum levels of prolactin $(\mathrm{ng} / \mathrm{mL}), \mathrm{FSH}(\mathrm{ng} / \mathrm{mL})$, luteinizing hormone $(\mathrm{LH})(\mathrm{mIU} / \mathrm{mL}), \mathrm{TSH}(\mathrm{mIU} / \mathrm{mL})$, and estradiol ($\mathrm{pg} / \mathrm{mL}$ ). Hormonal levels were obtained as part of the routine service between the $2^{\text {nd }}$ and $4^{\text {th }}$ day of the menstrual cycle.

The statistical difference between independent samples was evaluated by the non-parametric Wilcoxon Mann-Whitney test. To evaluate the differences between proportions, we used either the Chi-squared or the Fisher exact test. The significance level was $5 \%$. Statistical analyzes were performed with the support of IBM SPSS Statistis for Windows, Version 20.0 (IBM Corp., Armonk, NY, USA).

\section{Results}

A total of 7,200 medical records of infertile female patients who underwent assisted reproduction treatment were retrieved from LabRep, a human reproduction public health service. Based on the inclusion and exclusion criteria, a total of 263 medical records of patients with regular menstrual cycles were selected. The mean age of these patients was 31.9 years (SD: \pm 4.4 ), ranging from 20 to 40 years. A total of 124 out of 263 (47\%) were classified as having primary infertility and 139 out of 263 (53\%) presented secondary infertility. The mean duration of infertility was 70.2 months (SD: \pm 48.8 ).

The case and control groups were stratified according to the presence of the exposure variable (overweight) and matched. - Table 1 presents possible confounding variables that were analyzed among patients with normal weight and those with overweight. The studied groups were comparable for all the analyzed variables.

-Figure 1 demonstrates that medians of serum progesterone gradually decrease as the weight of patients increase. Patients with normal weight presented significantly higher medians of serum progesterone than both ranges of overweight patients (ranges III and IV). In this way, we performed two analyses regarding ovulatory cutoff point based on serum progesterone levels, using both WHO and ASRM cutoffs indicative of ovulation ( $>5.65 \mathrm{ng} / \mathrm{mL}$ and $\geq 10.0 \mathrm{ng} / \mathrm{mL}$ ).

Among the 263 patients who met the inclusion criteria, $224(85.2 \%)$ presented serum levels of progesterone $>5.65$ $\mathrm{ng} / \mathrm{mL}$, and 168 (63.9\%) presented serum levels $\geq 10.0 \mathrm{ng} / \mathrm{mL}$, in accordance with the WHO and the ASRM criteria for ovulation, respectively. Regarding the USG evaluation, a total of 193 (73.4\%) patients presented results indicative of ovulation. Patients were excluded if inconsistent ovulation was observed (serum progesterone level indicative of ovulation with no follicle collapse evidence by USG evaluation, or vice versa).

- Figure 2 demonstrates the distribution and characterization of patients as consistently ovulatory, anovulatory or inconsistently ovulatory using both cutoff points for serum progesterone levels.

Table 1 Clinical variables of infertile women with regular cycles with normal weight and overweight

\begin{tabular}{|c|c|c|c|c|c|c|c|}
\hline \multirow[t]{2}{*}{ Variables } & \multicolumn{3}{|c|}{$\begin{array}{l}\text { Normal weight } \\
\text { BMI } 18.5-24.9 \mathrm{~kg} / \mathrm{m}^{2}\end{array}$} & \multicolumn{3}{|c|}{$\begin{array}{l}\text { Overweight } \\
\text { BMI } 25.0-29.9 \mathrm{~kg} / \mathrm{m}^{2}\end{array}$} & \multirow[t]{2}{*}{$P$-value } \\
\hline & $\mathbf{n}$ & Mean & SD & $\mathbf{n}$ & Mean & SD & \\
\hline Age (years) & 168 & 31.48 & 4.45 & 95 & 32.26 & 4.27 & 0.163 \\
\hline Infertility duration (months) & 168 & 65.85 & 46.55 & 95 & 72.60 & 45.82 & 0.218 \\
\hline Prolactin (ng/mL) & 167 & 11.14 & 4.01 & 95 & 10.23 & 3.74 & 0.058 \\
\hline $\mathrm{FSH}(\mathrm{ng} / \mathrm{mL})$ & 166 & 6.08 & 1.54 & 93 & 5.92 & 1.56 & 0.350 \\
\hline LH (UI/L) & 155 & 4.39 & 2.02 & 89 & 4.06 & 1.98 & 0.201 \\
\hline TSH (mUl/L) & 166 & 1.94 & 0.95 & 91 & 1.87 & 0.91 & 0.592 \\
\hline Estradiol (ng/dL) & 157 & 51.11 & 27.09 & 87 & 48.67 & 30.34 & 0.197 \\
\hline
\end{tabular}

Abbreviations: BMI, body mass index; FSH, follicle-stimulating hormone; LH, luteinizing hormone; SD, standard deviation; TSH, thyroid-stimulating hormone. 


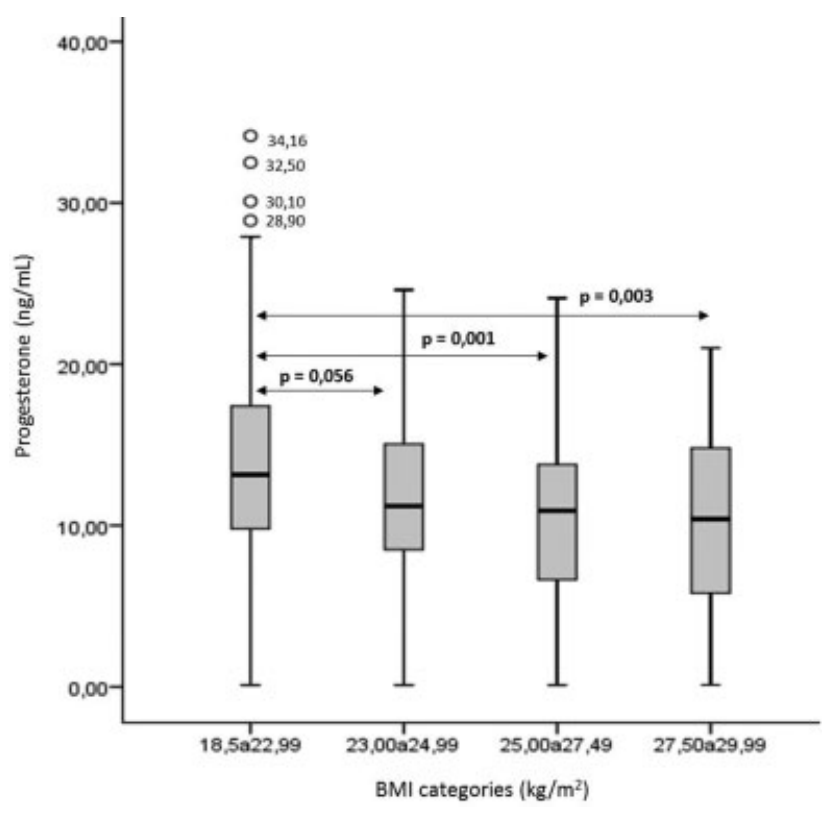

Fig. 1 Median of serum progesterone level among patients within different BMI categories: 18.50 to $22.99 \mathrm{~kg} / \mathrm{m}^{2}$ (Range I: normal weight); 23.00 to $24.99 \mathrm{~kg} / \mathrm{m}^{2}$ (Range II: normal weight); 25.00 to $27.49 \mathrm{~kg} / \mathrm{m}^{2}$ (Range III: overweight) and 27.50 to $29.99 \mathrm{~kg} / \mathrm{m}^{2}$ (Range IV: overweight).

When a serum progesterone level of $5.65 \mathrm{ng} / \mathrm{mL}$ was used as a cutoff point for ovulation, 61 out of 263 patients (23.2\%) were excluded due to inconsistent ovulation. From the remaining 202 patients (76.8\%) with consistently ovulatory or anovulatory status (confirmed with USG), 24 (11.9\%) were anovulatory and 178 (88.1\%) had a confirmed ovulation. Among the 178 consistently ovulatory patients, 117 (65.7\%) presented normal BMI, and 61 (34.3\%) were overweight. Regarding the 24 patients with consistent anovulation, $10(41.7 \%)$ were within normal BMI range and 14 (58.3\%) were considered overweight.
When using a cutoff point of $\geq 10 \mathrm{ng} / \mathrm{mL}$ for serum progesterone level, 77 out of 263 patients (29.3\%) presented inconsistent ovulation and were excluded. A total of 186 patients was then analyzed: $44(23.7 \%)$ characterized as consistently anovulatory and 142 (76.3\%) characterized as consistently ovulatory. Among the 142 consistently ovulatory patients, 94 (66.2\%) presented normal BMI and 48 (33.8\%) were overweight. From the remaining 44 anovulatory patients, 23 (52.3\%) were within normal BMI range and 21 (47.7\%) were considered overweight.

- Table 2 describes the association analyses for body weight and anovulation in this study group when using different thresholds for ovulation based on the serum progesterone level. Consistently anovulatory overweight women (characterized by serum progesterone $\leq 5.65 \mathrm{ng} / \mathrm{mL}$ and anovulation by ultrasound) were more than twice as likely to have anovulation when compared with those with normal weight (odds ratio [OR]: 2.69;CI 95\%: 1.04-6.98; p: 0.022). However, no significant difference (OR: 1.79; CI95\%: 0.794.10; p: 0.130) was observed among overweight women and those with normal weight diagnosed with consistently anovulation (characterized by serum progesterone $<10.0 \mathrm{ng} / \mathrm{mL}$ and anovulation by ultrasound).

\section{Discussion}

In the present study, we observed that overweight increases more than twice the chance of anovulation among infertile women with regular menstrual cycles, with no previous diagnosis of polycystic ovary syndrome. This effect was observed when serum progesterone level $>5.65 \mathrm{ng} / \mathrm{mL}$ was used as an indication of ovulation. However, when progesterone levels $\leq 10.0 \mathrm{ng} / \mathrm{mL}$ and USG with no indication of follicular collapse were used as anovulation criteria, this difference was not observed. These findings corroborate the notion that excessive body weight contributes to
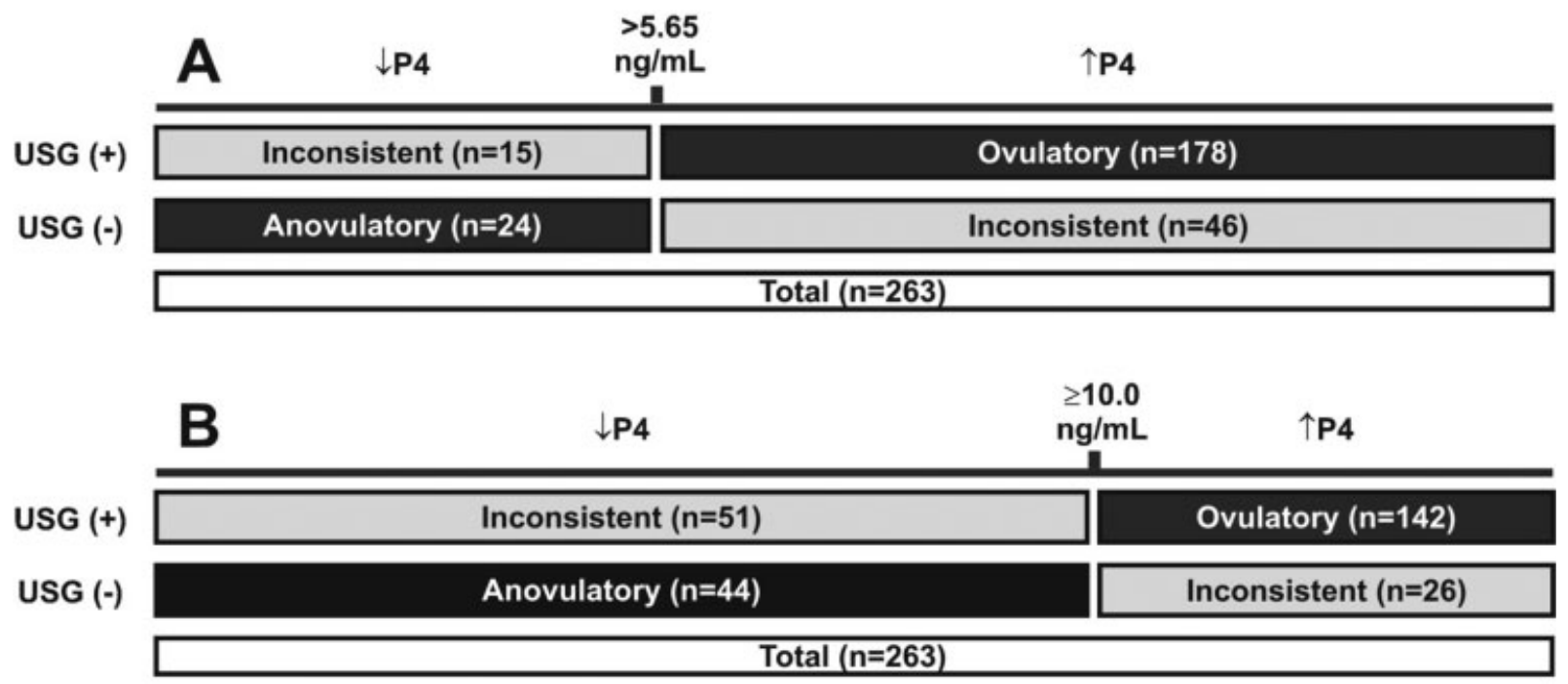

Fig. 2 Characterization of infertile women as consistently ovulatory, anovulatory or inconsistently ovulatory using different cutoff points for serum progesterone levels and ultrasonography evidence of ovulation. A. Serum progesterone cutoff used for ovulation: $>5.65 \mathrm{ng} / \mathrm{mL}$. B. Serum progesterone cutoff used for ovulation: $\geq 10.0 \mathrm{ng} / \mathrm{mL}$. $\downarrow$ P4: low level of serum progesterone; $\uparrow$ P4: high level of serum progesterone; USG (+): evidence of follicle collapse at ultrasonography; USG (-): lack of evidence of ovulation at ultrasonography. 
Table 2 Distribution of infertile women with regular cycles according to consistent ovulation and overweight for both cutoff points of serum progesterone

\begin{tabular}{|c|c|c|c|c|c|}
\hline $\begin{array}{l}\text { BMI Categories } \\
\left(\mathrm{kg} / \mathrm{m}^{2}\right)\end{array}$ & $\begin{array}{l}\text { Anovulatory } \\
\text { n (\%) }\end{array}$ & $\begin{array}{l}\text { Ovulatory } \\
\text { n (\%) }\end{array}$ & $P$-value & Odds ratio (OR) & $\mathrm{Cl} 95 \%$ \\
\hline \multicolumn{6}{|l|}{$\mathrm{P} 4>5.65 \mathrm{ng} / \mathrm{mL}$} \\
\hline $\begin{array}{l}\text { Overweight } \\
25.0-29.9\end{array}$ & $14(58.3)$ & $61(34.3)$ & 0.022 & 2.69 & $1.04-6.98$ \\
\hline $\begin{array}{l}\text { Normal weight } \\
18.5-24.9\end{array}$ & $10(41.7)$ & $117(65.7)$ & & & \\
\hline \multicolumn{6}{|l|}{$\mathrm{P} 4 \geq 10.0 \mathrm{ng} / \mathrm{mL}$} \\
\hline $\begin{array}{l}\text { Overweight } \\
25.0-29.9\end{array}$ & $21(47.7)$ & $48(33.8)$ & 0.095 & 1.79 & $0.85-3.75$ \\
\hline $\begin{array}{l}\text { Normal weight } \\
18.5-24.9\end{array}$ & $23(52.3)$ & $94(66.2)$ & & & \\
\hline
\end{tabular}

Abbreviations: BMI, body mass index; $\mathrm{Cl}$, confidence interval; $\mathrm{P} 4$, serum progesterone.

infertility by affecting ovulation, probably by altering endocrine mechanisms. ${ }^{6,16,17}$

The increase in body weight is the main determinant of insulinemia, insulin sensitivity, and ovarian hyperandrogenism. ${ }^{18}$ Therefore, women who are overweight or obese may have altered endocrine profiles such as high $\mathrm{LH}$, abnormal ratio of FSH and $\mathrm{LH}$, low progesterone in the luteal phase, and low levels of sex hormone-binding globulin. ${ }^{19}$

We observed that the serum progesterone levels gradually decreased as the weight of patients increased, and a significant difference in the serum levels of progesterone was observed between the normal weight and the overweight groups. This finding corroborates previous studies demonstrating that overweight women have low levels of serum progesterone during the luteal phase. ${ }^{19}$ The use of progesterone levels alone for the diagnosis of ovulation is controversial, since the progesterone release is a pulsatile phenomenon and, therefore, varies during the day. However, serum progesterone level is commonly used as a markerfor ovulatory activity and measure of luteal function quality. ${ }^{15,20}$

Regarding the weight classification, BMI is a marker routinely used for overweight and obesity. However, there is a lack of standardization of the indicative cutoff for overweight and obesity. Additionally, different BMI cutoff points for different ethnic groups should be considered as body fat percentage and distribution differ among populations.

Although previous studies demonstrated the association between anovulation and overweight, the high heterogeneity among them jeopardizes comparability. The present study provides important information for the assisted reproduction field as it demonstrates a significant association between overweight and anovulation among infertile patients with regular menstrual cycles and no diagnosis of obesity or polycystic ovary syndrome.

\section{Conclusion}

We concluded that overweight can negatively influence the ovulatory profile of infertile women with regular cycles, when using the recommended criteria for ovulation by the
WHO (serum progesterone level $>5.65 \mathrm{ng} / \mathrm{ml}$ and ultrasound evidence). However, no association was observed when the serum progesterone level threshold for ovulation was $\geq 10.0$ $\mathrm{ng} / \mathrm{mL}$. Further studies are needed to evaluate different cutoff points for progesterone serum levels used as criteria for ovulation. Additionally, information regarding the frequency of anovulation among women with regular cycles and the impact of overweight in assisted reproduction treatments and pregnancy outcome should be further evaluated.

\section{Contributions}

C. R. G. contributed in the study design, data analysis and manuscript writing; E. G. M. S. contributed in the study design and data analysis; Y.A.R.L. contributed in the study design and data analysis; M. S. A. contributed in the study design, data analysis, and interpretation and manuscript writing. All authors have seen, reviewed, and approved the final version of the manuscript.

\section{Conflict of Interests}

The authors have no conflict of interests to declare.

\section{References}

1 Hensrud DD, Klein S. Extreme obesity: a new medical crisis in the United States. Mayo Clin Proc. 2006;81(10, Suppl)S5-S10. Doi: 10.1016/s0025-6196(11)61175-0

2 Love JG, McKenzie JS, Nikokavoura EA, Broom J, Rolland C, Johnston KL. The experiences of women with polycystic ovary syndrome on a very low-calorie diet. Int J Womens Health. 2016; 8:299-310. Doi: 10.2147/IJWH.S100385

3 Kuchenbecker WK, Groen H, Zijlstra TM, Bolster JH, Slart RH, van der Jagt EJ, et al. The subcutaneous abdominal fat and not the intraabdominal fat compartment is associated with anovulation in women with obesity and infertility. J Clin Endocrinol Metab. 2010;95(05):2107-2112. Doi: 10.1210/jc.2009-1915

4 Hollmann M, Runnebaum B, Gerhard I. Effects of weight loss on the hormonal profile in obese, infertile women. Hum Reprod. 1996;11 (09):1884-1891. Doi: 10.1093/oxfordjournals.humrep.a019512

5 Buck GM, Sever LE, Batt RE, Mendola P. Life-style factors and female infertility. Epidemiology. 1997;8(04):435-441. Doi: 10.1097/00001648-199707000-00015 
6 Loret de Mola JR. Obesity and its relationship to infertility in men and women. Obstet Gynecol Clin North Am. 2009;36(02):333-346, ix

7 Sadia S, Waqar F, Akhtar T, Sultana S. Characteristics of infertile patients with ovulatory dysfunction and their relation to body mass index. J Ayub Med Coll Abbottabad. 2009;21(03):12-16

8 Weiss RV, Clapauch R. Female infertility of endocrine origin. Arq Bras Endocrinol Metabol. 2014;58(02):144-152. Doi: 10.1590/0004-2730000003021

9 Parihar M. Obesity and infertility. Rev Gynaecol Pract. 2003;3(03): 120-126. Doi: 10.1016/S1471-7697(03)00061-3

10 Zain MM, Norman RJ. Impact of obesity on female fertility and fertility treatment. Womens Health (Lond). 2008;4(02):183-194. Doi: $10.2217 / 17455057.4 .2 .183$

11 Tamer Erel C, Senturk LM. The impact of body mass index on assisted reproduction. Curr Opin Obstet Gynecol. 2009;21(03): 228-235. Doi: 10.1097/GCO.0b013e32832aee96

12 Chavarro JE, Ehrlich S, Colaci DS, Wright DL, Toth TL, Petrozza JC, et al. Body mass index and short-term weight change in relation to treatment outcomes in women undergoing assisted reproduction. Fertil Steril. 2012;98(01):109-116. Doi: 10.1016/j.fertnstert.2012.04.012

13 Lashen H, Ledger W, Bernal AL, Barlow D. Extremes of body mass do not adversely affect the outcome of superovulation and invitro fertilization. Hum Reprod. 1999;14(03):712-715. Doi: 10.1093/humrep/14.3.712
14 Maheshwari A. Overweight and obesity in infertility: cost and consequences. Hum Reprod Update. 2010;16(03):229-230. Doi: 10.1093/humupd/dmp058

15 Practice Committee of the American Society for Reproductive Medicine. Diagnostic evaluation of the infertile female: a committee opinion. Fertil Steril. 2015;103(06):e44-e50. Doi: 10.1016/j.fertnstert.2015.03.019

16 Nelson SM, Fleming RF. The preconceptual contraception paradigm: obesity and infertility. Hum Reprod. 2007;22(04):912-915. Doi: 10.1093/humrep/del473

17 Bongain A, Isnard V, Gillet JY. Obesity in obstetrics and gynaecology. Eur J Obstet Gynecol Reprod Biol. 1998;77(02):217-228. Doi: 10.1016/s0301-2115(97)00247-9

18 Dravecka I, Lazurova I, Kraus V. Obesity is the major factor determining an insulin sensitivity and androgen production in women with anovulary cycles. Bratisl Lek Listy. 2003;104(12): 393-399

19 Lash MM, Armstrong A. Impact of obesity on women's health. Fertil Steril. 2009;91(05):1712-1716. Doi: 10.1016/j.fertnstert.2008.02.141

20 Rowe PJ, Comhaire FH, Hargreave TB, Mellows HJWorld Health Organization. WHO manual for the standardized investigation and diagnosis of the infertile couple. Cambridge: Cambridge University Press; 1993 